\title{
CYTOTOXICITY ACTIVITY OF SOME INDIAN MEDICINAL PLANTS
}

\author{
DORA BABU NEERUGATTI $1{ }^{1}{ }^{*}$ GANGA RAO BATTU2 ${ }^{2}$, RAVITEJA BANDLA ${ }^{3}$
}

1Department of Pharmacognosy and Phytochemistry, Santhiram College of Pharmacy, Nandyal, Kurnool, Andhra Pradesh, India 518502, ${ }^{2}$ Pharmacognosy and Phytochemistry, Andhra University, Visakhapatnam Andhra Pradesh 530003, ${ }^{3}$ Pharmaceutical Chemistry Department, MAM College of Pharmacy, Narasaraopet, Andhra Pradesh, India 522601

Email: dr.dorababun@gmail.com

Received: 25 Jul 2016, Revised and Accepted: 17 Sep 2016

ABSTRACT

Objective: The current study is carried out to evaluate cytotoxicity activity of the methanolic extracts of some medicinal plants (Buchanania axillaris Desr, Tamilnadia ulignosa Retz, Phaseolus semierectus L and Stylosanthes fruticosa Retz).

Methods: Cytotoxicity activity was evaluated on human cancer cell lines such as lung cancer (A549) and skin cancer (A431) using MTT assay method.

Results: The selected plant extracts showed the dose-dependent cytotoxicity activity on the tested cell lines. The cytotoxicity variations on different cell lines were also observed for tested plants extracts. The cytotoxicity of the extracts was increased as the concentration of them was increased. Among all tested plants extracts Phaseolus semierectus showed the better cytotoxicity activity on tested cell lines.

Conclusion: The results of the present study supported the folkloric usage of the studied plants and confirmed that the plant's extracts have the bioactive constituents with cytotoxic properties and their isolation can be useful for developing new anticancer drugs.

Keywords: Cytotoxicity, Lung cancer, Skin cancer, Cell lines and MTT assay

(C) 2016 The Authors. Published by Innovare Academic Sciences Pvt Ltd. This is an open access article under the CC BY license (http://creativecommons.org/licenses/by/4.0/) DOI: http://dx.doi.org/10.22159/ijcpr.2016v8i4.15687

\section{INTRODUCTION}

Cancer is one of the major diseases in the world causing mortality around the world. Cancer is the uncontrolled proliferation of the cells in any part of the body causes bulge of organ or tumor of the cells, which are not advantage to the body. The habitually affecting parts of the body are mainly lungs, liver, cervical, breast, stomach, oral, etc [1]. The cancer spreads through the metastasis from affecting part of the body to other parts. Lung cancer and skin cancer are two main cancers affecting the humans on their habitual conditions. Lung cancer is mainly due to smoking, secondhand smoke, exposure to toxins, etc [2, 3]. Skin cancer due to carcinogens, smoking, chronic and subchronic wounds, use of immunosuppressive drugs [4, 5]. At present, chemotherapy is the usually use treatment for cancer includes alkylating agents, antimetabolites, antitumor antibiotics, platinum analogs, all may indirectly leads skin or lung cancer and undesirable side effects on their long-term use in treatment. So, there is a necessitate to identify the new molecules for the treatment of cancer with low prices, high efficient curing, less side effects. The natural medicinal plants have been using in treatment for different diseases including cancer since olden days [6]. But there is no scientific evidence on some medicinal plants of their biological activities. In this point of view, we aimed the present study to evaluate the in vitro cytotoxicity activity of some traditional medicinal plants of India $[7,8]$ on lung and skin cancer cell lines.

\section{MATERIALS AND METHODS}

\section{Plant material collection and preparation of extracts}

Buchanania axillaris Desr, Tamilnadia ulignosa Retz, Phaseolus semierectus L and Stylosanthes fruticosa Retz were collected from of the Thalakona region, Chittoor district, India. The plant specimen was authenticated by Dr. K. Madhava Chetty, Department of Botany, Sri Venkateswara University, Thirupati. The plant materials were shade dried, then powdered in the mill and extracted separately with methanol using soxhlet extraction process.

\section{Cell lines}

A549 cell line for lung cancer and A431 cell lines for skin cancer were used for the present study.

\section{Cytotoxic assay}

MTT assay method is a Colorimetric, nonradioactive, fast and economical assay widely used to quantify cell viability and proliferation of mammalian cells. So, the cytotoxicity of the selected plant's methanolic extracts was tested using MTT assay $[9,10]$. The yellow tetrazolium MTT (3-(4, 5-dimethylthiazolyl-2)-2, 5diphenyltetrazolium bromide) is reduced by metabolically active cells, in part by the action of dehydrogenase enzymes, to generate reducing equivalents such as NADH and NADPH. The resulting intracellular purple formazan can be solubilized and quantified by spectrophotometric means. Absorbance values that are lower than the control cells indicate a reduction in the rate of cell proliferation. Conversely, a higher absorbance rate indicates an increase in cell proliferation. Evidence of cell death may be inferred from morphological changes.

\section{RESULTS AND DISCUSSION}

Plants have been using in treatment for various diseases before the modern medicine [11]. The synthetic drugs using in modern medicine for treatment have the roots from naturally isolated compounds, especially medicinal plants [12]. But the long-term use of the synthetic drugs are causing unwanted side effects and decreases the immunity towards the normal diseases. Natural products, mainly medicinal plants are a significant source for the discovery of new bioactive molecules with high efficiency, fewer side effects [13]. In this point of view, the present study was done to identify the cytotoxicity (Anticancer) activity of Buchanania axillaris, Tamilnadia ulignosa, Phaseolus semierectus and Stylosanthes fruticosa on A549 cell line for lung cancer and A431 cell lines for skin cancer.

The selected plant extracts showed the dose-dependent cytotoxicity activity on the tested cell lines (fig. 1,2). The cytotoxicity variations on different cell lines were observed for selected plants extracts. The $\mathrm{IC}_{50}$ values are showed in table 1 . The cytotoxicity of the extracts was increased as the concentration of them was increased. The selected plants B. axillaris, T. ulignosa, P. semierectus and S. fruticosa have been using by people around the southern parts of the India for treating the diseases $[7,8]$. 
T. ulignosa, methanolic extract showed more cytotoxic activity on A549 cell lines compared to other plants methanolic extracts. The IC $_{50}$ values of B. axillaris, P. semierectus and S. fruticosa on A549 cell lines were $98.40 \pm 0.61,75.67 \pm 3.76,133.04 \pm 8.37$ on MCF-7, MDA-MB and HT-29 cell lines respectively. The selected plants $S$. fruticosa and B. axillaris do not showed the cytotoxic effect on A431 cell lines, but $P$. semierectus and T. ulignosa showed the cytotoxic activity with IC50 values $115.37 \pm 1.93$ and $162.30 \pm 9.52$. The variation of activity on lung cancer and skin cancer cell lines was observed this variance may be because of chemical compounds response present in them.

Cancer is the unconditional growth of the cells in the affected, to decrease the effect of the cancers, the unconditional growth of the cell number have to decrease. Till now, there is no accurate treatment for cancer, but the unconditionally increased cell number due to cancer were decreasing by the affecting the cell metabolic pathways to kill them [14]. The cytotoxic effect of the selected plant extracts may be due to the killing of abnormally growing cells due to cancer and the killing of those cell by apoptosis or necrosis process $[15,16]$. Apoptosis is activation of endonucleases causes doublestrand breaks in DNA between nucleosomes leading to that DNA is fragmented into multiples pieces leads to cell death. Necrotic cell death is an unregulated process resulting from severe damage, such as ATP depletion, hypoxia, various toxins and hyperthermia and characterized by cell swelling, lysis, and the release of intracellular contents associated with pathological tissue injury $[16,17]$. Plants have diverse chemical constituents in them for their metabolic activities at the same time defense from their predators i.e. the compounds which protect the plants are may be responsible for increasing the cancer cells mortality. The additional study is required to separate the pure compounds and their derivatives from the chosen plants which are responsible cytotoxicity.

Table 1: IC 50 values for test extracts (B. axillaris, $T$. ulignosa, $P$. semierectus and $S$. fruticosa) after performing cytotoxicity assay (MTT assay) for 24h on A549 and A431cell lines

\begin{tabular}{lll}
\hline & $\mathbf{A 5 4 9}$ & $\mathbf{A 4 3 1}$ \\
\hline BAM & $98.40 \pm 0.61$ & NA \\
TUM & $32.74 \pm 3.20$ & $162.30 \pm 9.52$ \\
PSM & $75.67 \pm 3.76$ & $115.37 \pm 1.93$ \\
SFM & $133.04 \pm 8.37$ & NA \\
\hline
\end{tabular}

Values are mean \pm SD, $n=$ triplicate experiment

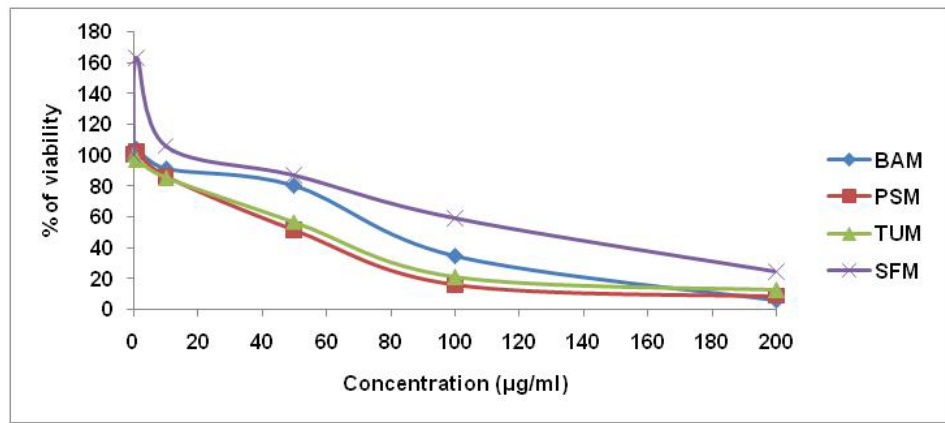

Fig. 1: Graphical representation of Cytotoxicity of the test extracts (B. axillaris, T. ulignosa, P. semierectus and S. fruticosa) on A549 cell line, All values are mean $\pm S D, n=$ triplicate experiment After $24 \mathrm{~h}$ exposure

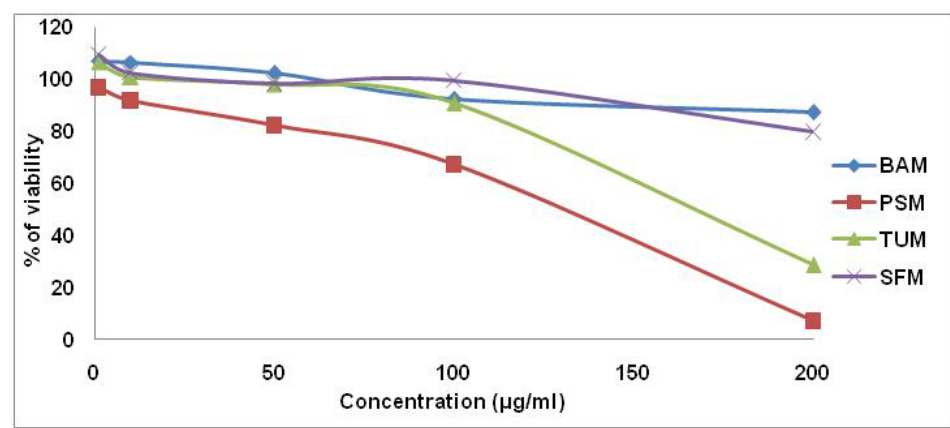

Fig. 2: Graphical representation of Cytotoxicity of the test extracts (B. axillaris, T. ulignosa, P. semierectus and S. fruticosa) on A431 cell line, All values are mean $\pm S D, n=$ triplicate experiment After $24 \mathrm{~h}$ exposure

\section{CONCLUSION}

The present study showed that the selected traditional medicinal plants possess the cytotoxic activity on lung and skin cancer cell lines.

\section{ACKNOWLEDGEMENT}

The authors would like to thank the TATA memorial center, Advanced Centre for Treatment, Research and Education in Cancer (ACTREC), Kharghar, Mumbai, India for providing the cancer cell lines and their help in doing the anti-cancer activity successfully.

\section{CONFLICT OF INTERESTS}

Declared none

\section{REFERENCES}

1. World Cancer Report. World Health Organization. Chapter 5.1; 2014.

2. Underner M, Urban T, Perriot J. Cannabis smoking and lung cancer. Rev Mal Respir 2014;31:488-98.

3. Sood A. Indoor fuel exposure and the lung in both developing and developed countries: an update. Clin Chest Med 2012;33:649-65. 
4. Saladi RN, Nektalova T, Fox JL. Induction of skin carcinogenicity by alcohol and ultraviolet light. Clin Exp Dermatol 2010;35:7-11.

5. Jump up Kuschal C, Thoms KM, Schubert S, Schäfer A Boeckmann L, Schön MP, et al. Skin cancer in organ transplant recipients: effects of immunosuppressive medications on DNA repair. Exp Dermatol 2012;21:2-6.

6. Cragg GM, Newman DJ. Plants as a source of anti-cancer agents. J Ethnopharmacol 2005;100:72-9.

7. Madhava CK, Sivaji K, Tulasi RK. Flowering plants of Chittoor district Andhra Pradesh. Students Offset Printers 2008;1:101.

8. Venkata KR, Venkata RRR. Traditional medicine used by the Adivasis of Eastern Ghats, Andhra Pradesh-for bone fractures. Ethnobotanical Leaflets 2008;12:19-22.

9. Mosmann T. Rapid colorimetric assay for cell growth and survival: application to proliferation and cytotoxicity assay. J Immunol Methods 1983;65:55-63.

10. Denizot F, Lang R. Rapid colorimetric assay for cell growth and survival. Modification to the tetrazolium dye procedure giving improved sensitivity and reliability. J Immunol Methods 1986;89:271-7.

11. Mahmoud Rafieian Kopaei. Medicinal plants and the human needs. J HerbMed Pharmacol 2012;1:1-2.
12. Haile T Debas, Ramanan Laxminarayan, Stephen E. Straus complementary and alternative medicine. Chapter 69; 2006.

13. Bharat B Aggarwal, Haruyo Ichikawa, Prachi Garodia, Priya Weerasinghe, Gautam Sethi, Indra D Bhatt, et al. Traditional ayurvedic medicine to modern medicine: identification of targets for suppression of inflammation and cancer. Expert Opin Ther Targets 2006;10:87-118.

14. Wyllie AH. The biology of cell death in tumors. Anticancer Res 1985;5:131-6.

15. Cocco RE, Ucker DS. Distinct modes of macrophage recognition for apoptotic and necrotic cells are not specified exclusively by phosphatidylserine exposure. Mol Biol Cell 2001;12:919-30.

16. Igney FH, Krammer PH. Death and anti-death: tumor resistance to apoptosis. Nat Rev Cancer 2002;2:277-88.

17. Martinou JC, Green DR. Breaking the mitochondrial barrier. Nat Rev Mol Cell Biol 2001;2:63-7.

\section{How to cite this article}

- Dora Babu Neerugatti, Ganga Rao Battu, Raviteja Bandla. Cytotoxicity activity of some Indian medicinal plants. Int J Curr Pharm Res 2016;8(4):86-88. 